\title{
RÁCZ EMESE
}

\section{Benkő József nagyenyedi hungarika könyvjegyzéke}

Benkő József (1740-1814) Collectaria ad res Transsilvanicas facientia ${ }^{1}$ címü - Erdély történelmére vonatkozó latin és magyar nyelvü források eredetijét, valamint másolatait tartalmazó - kéziratgyüjteménye két olyan terjedelmes könyvjegyzéket foglal magában, amely mindeddig elkerülte az erdélyi könyv- és könyvtártörténet kutatók figyelmét.

A kézirat-kolligátumban a két egymás mellé füzött könyvjegyzék különböző kézírással íródott. Az első, cím nélküli, betürendes jegyzéket ${ }^{2}$ Benkő József Nagyenyeden másolta le, keltezése alapján 1762. szeptember 16-án. Teológus hallgatóként 1761-1766 között a nagyenyedi Bethlen Kollégiumban diákoskodó Benkőnek ${ }^{3}$ a tudomány iránti affinitása, illetve a régi kéziratok iránti gyüjtőszenvedélye már ekkor megmutatkozott. Ez idő tájt vásárolta meg - az 1735től nagyenyedi lelkészként tevékenykedő nagybátyja - Hermányi Dienes József (1699-1763) halálát követően elárverezett kéziratgyüjteményének egy részét, amelynek megrongálódott darabjairól másolatokat készített, ${ }^{4} \mathrm{~s}$ ugyancsak enyedi diákként másolhatta le a fent említett könyvjegyzéket is, amely - meglátásunk szerint - a nagyenyedi Bethlen Könyvtár Hungarika tékájának 1762. esztendő utáni állapotát tükrözi.

A Collectaria ad res Transsilvanicas facientia... második könyvjegyzéke az enyedi Bethlen Könyvtár hungarika-gyüjteményének - a szakirodalom számára eddig ismeretlen - katalógusát tartalmazza, hat ordóba (polcon) csoportosítva. A könyvjegyzék formai felépítése azonos a nagyszebeni Brukenthal Könyvtárban található Catalogus ordinum librorum Illustris Colegii Alba N:Enyediensis renovatus sub B(iblio)Thecariam Andreae Benedek de K.Batzon Anno MDCCLXIVdiebus July címü kéziratos katalógussal, úgy tünik, egyazon kézírással készültek.

A Bethlen Könyvtár 18. századi gyüjteményének rekonstruálását mindeddig két, kéziratban maradt könyvkatalógus alapján valósíthattuk meg: az 1752-ben

${ }^{1}$ Benkö József, Collectaria ad res Transsilvanicas facientia, Tom. 14. in Quatro, jelzete a Kolozsvári Egyetemi Könyvtárban (továbbiakban KvEKt): Ms. 1369.

2 Uo. $343 \mathrm{v}-358 \mathrm{r}$.

${ }^{3}$ SzINNYEI József, Magyar irók élete és munkái, Reprint kiadás, Bp., 1980-1981, 861 col.

${ }^{4}$ Mikó Imre, Benkö József élete és munkái, Pest, 1867, 15-17.

${ }^{5}$ A Bethlen Könyvtár 18. századi gyüjteményének rekonstruálása a két könyvkatalógus öszszevetése alapján folyamatban van. 
Szilágyi N. Márton által indított betürendes katalógus, illetve az 1764-ben Kisbaconi Benedek András készítette katalógus alapján. Az 1752-ben indított katalógus betürendben regisztrálja a könyvtár állományát, megjelölve ugyanakkor az egyes könyveknek a polcon elfoglalt helyét is (pl. Th. Borosnyai ordo 2. liber 8.). ${ }^{6} \mathrm{Az} 1764$-es katalógus ${ }^{7}$ a mai értelemben vett helyrajzi katalógusnak felel meg, a könyvállományt az egyes könyveknek a polcokon való elrendezési sorrend szerint regisztrálta tíz tékába: Teleki József (1675-1732), Bánffy Zsigmond (?-1685), Borosnyai Nagy Márton (?-1738) adományain kívül a könyvtár északi (septentrionalis), keleti (orientalis), illetve déli (meridionalis) részein elhelyezett tékáit jegyzi. Ezek a különálló gyüjtemények a katalógusban polcok szerint voltak feljegyezve: például a Teleki téka 10 polcos (ordo) volt. A felsoroltakhoz hasonlóan az újonnan elökerült jegyzékben a Theca Hungarica hat polcon helyezkedett el, s ekként került feljegyzésre. Segítségével immár a könyvtár teljes gyüjteménye feltérképezhető.

E második hungarika-könyvjegyzék feldolgozása folyamatban van, részletes ismertetésére egy későbbi tanulmányban térünk vissza, annyit azonban előrebocsáthatunk, hogy a két jegyzék közül e második valamivel gazdagabb hungarikakollekciót regisztrál: 401 müvet 429 kötetben.

A nagyenyedi Bethlen Könyvtár eddig elökerült 18. századi katalógusai

\begin{tabular}{|l|l|l|l|}
\hline 1752 & A katalógus címe & $\begin{array}{l}\text { A katalógus } \\
\text { készítóje }\end{array}$ & $\begin{array}{l}\text { Jelenlegi } \\
\text { lelöhelye }\end{array}$ \\
\hline 1764 & $\begin{array}{l}\text { Catalogus Alphabeticus Librorum } \\
\text { Illustris Collegii Alba } \\
\text { N:Enyediensis renovatus Anno } \\
\text { MDCCLII diebus Novembris }\end{array}$ & $\begin{array}{l}\text { Szilágyi } \\
\text { N. Márton } \\
\text { N:Enyediensis renovatus sub } \\
\text { B.(iblio)Thecariatii Andreae Benedek de } \\
\text { K.Batzon Anno MDCCLXIVdiebus July. }\end{array}$ & $\begin{array}{l}\text { Bethlen Gábor } \\
\text { Dokumentációs } \\
\text { Könyvtár, } \\
\text { Nagyenyed }\end{array}$ \\
\hline 1762 & $\begin{array}{l}\text { Kenedek András } \\
\text { Theca Hungarica }\end{array}$ & $\begin{array}{l}\text { Brukenthal Könyvtár, } \\
\text { Nagyszeben }\end{array}$ \\
\hline
\end{tabular}

Rejtély maradt, miként kerülhetett az enyedi könyvtár Theca Hungaricájának eredeti katalógusa Benkő József tulajdonába. Feltételezzük, hogy kölcsönkérte

${ }^{6}$ Vö. Dankanits Ádám, A Nagyenyedi Bethlen-könyvtár 1752. évi katalógusa = Könyvtárosok tájékoztatója, 1959, 3.

${ }^{7}$ Vö. MоNoK István, A nagyenyedi kollégium 1764. évi katalógusa = Fülöp Géza emlékkönyv: müvelödéstörténeti és könyvtártudományi irások, szerk. Barátné Hajdú Ágnes, Bp., ELTE Könyvtártudományi és Informatikai Tanszék, 1999, 127-130. 
a kéziratos könyvjegyzéket munkájához, majd utólag annak visszaszolgáltatására már nem került sor. Az enyedi könyvtár gyüjteményére vonatkozó korábbi és újabb kutatások nem egy olyan dokumentumot hoznak nyilvánosságra, amely annak köszönhetően élte túl a könyvtár 1849-es pusztítását, hogy azt megelözően valaki kölcsönkérte. Borosnyai Nagy Márton (?-1738) Album Amicoruma ${ }^{9}$ napjainkban a kolozsvári Egyetemi Könyvtár tulajdonát képezi, egykor azonban az enyedi könyvtár gyüjteményének volt a része. A provenienciát igazolja a kézirat kötéstáblájának belsején lévő jelzet: Th. Borosnyai ord. 9. lib. 1, amely azt tanúsítja, hogy a kéziratot az enyedi könyvtár Borosnyai tékájában regisztrálták. Hasonlóképpen bukkant fel Bethlen Kata ex librisével ellátott egyik könyve a nagyenyedi minoriták régikönyves gyüjteményében. ${ }^{10}$ Benkő József közismert gyüjtőszenvedélyéről számunkra releváns tájékoztatást nyújt Kazinczy Ferenc Teleki Lászlóhoz intézett egyik levele. Ebben a levélben arra hívja fel Teleki figyelmét, hogy enyedi látogatása során, a könyvtárban Benkő József kéziratai között, Teleki Mihálynak címezett 204 autentikus levelet látott. Kazinczy úgy vélekedik, Benkő jogtalanul tulajdonította el a Teleki család leveleit. ${ }^{11}$

Visszatérve az enyedi kollégium 1764-es kéziratos katalógusához, Monok István a könyvjegyzéket ismertető tanulmányában ${ }^{12}$ felvetette azt a kérdést, vajon

${ }^{8}$ Benkő József Synodi Erdődiensis című másolata úgy menekült meg az 1849-es pusztulástól, hogy a kéziratot Salamon Ferenc kölcsönözte, majd tőle Mikó Imréhez került, s mivel az Erdélyi Múzeum-Egylet könyvtára már rendelkezett egy példánnyal, 1862-ben a kézirat visszakerült Nagyenyedre. MusnaI László, A Bethlen Kollégium Nagykönyvtárának értékes kéziratai $=$ Református Szemle, 1940, 118.

${ }_{9}$ Album hoc Illustribus, Clarissimis, Egregiis etc. Nominibus Fautorum, Benevolore, Professore, Amicore, Condiscipulore et Suorum Sacrum esse voluit Possesor Martinus NAGY BOROSNYAI Transylvano-Hungarae - KvEKt, jelzete: Mss. 671.

${ }^{10}$ DoBner, Abraham Aegidius, Sopronyi puros tyukmony..., Kassa, 1719. (242) = RÁcz Emese, Az egykori nagyenyedi minorita rendház könyvtárának régi állománya, Bp., Kolozsvár, OSZK, BCU „Lucian Blaga”, 2009 (A Kárpát-medence magyar könyvtárainak régi könyvei, 3).

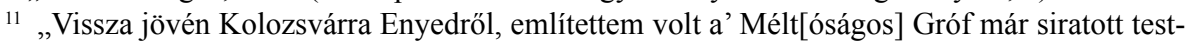
vérének, hogy az Enyedi Bibliothéca a’ Teleki háznak olly kincsét bírja, mellyet hihető, vagy ellopott Benkő József, vagy kölcsön vett volt 's vissza nem adott. 204 originalis levél a' Telekiektől és a' Telekiekhez, nevezetesen Mihályhoz, együvé varrva, vagy kötve, 'a Benkő M[anu]S[criptumai] köztt áll ott. Én tudom mit kíván tőlem a Moralitás, 's az a' megbecsülhetetlen jóság, a' mellyet Enyeden erántam mind Ö Exc[elenciája] a' Colégium' mostani Curátora, mind a' Professorok bizonyítottak: de a háládatosság itt conflictusba jő a' Moralitásnak eggy más parancsolatjával, mely azt kívánja, hogy adjak hírt a' tulajdonosnak, hol van elveszett portékája, és hogy ezt a megholt grófnak, s most a Mélt[óságos] Grófnak is kijelentem, magam előtt nem szégyenlem. Azonban előre látván, hogy az Enyedieknek épen nem volna kedves, ha megtudnák, hogy 'a hospitálást így fizetem: alázatosan kérem 'a Mélt[óságos] Grófot, méltóztassék a nevemet elhallgatni. Én, ha az én familiámat illető papírosok jutottak volna oda, azt az ajánlást tettem volna nekik, hogy azokat nekik leiratom, de az Originálokat semmi áron nem hagynám ott.” L.: Irodalomtörténeti levelek a gróf Teleki család gyömröi levéltárából, - közli Iványi Béla, 9. Kazinczy Ferencz levelei gróf Teleki Lászlóhoz = Irodalomtörténeti Közlemények, 1918, 1, 107.

12 Monok 1999, i. m. 127-130. 
a Theca Hungarica jegyzéke miért nem jelenik meg a szóban forgó katalógusban, holott ekkor már kétségtelenül a könyvtár gyüjteményének volt a része. Benkő kéziratgyüjteményében felbukkanó katalógus megválaszolja a rejtélyt: az enyedi könyvtár hungarika-gyüjteménye különálló nyilvántartással rendelkezett, melyet nem csatoltak a kisbaconi Benedek András által 1764-ben indított katalógushoz. A két könyvjegyzék formátuma is különbözik egymástól, ami arra enged következtetni, hogy már kezdetben az a szándék vezette a könyvek regisztrálóit, hogy a Hungarika téka külön nyilvántartásban maradjon.

Az enyedi Hungarika téka eddig ismert forrásai:

Bethlen Kata könyvtárának jegyzékei

Köztudott, hogy az enyedi könyvtár hungarika-gyüjteményét Bethlen Kata (17001759) könyvadománya alapozta meg, ennek nagy része még Bethlen Kata halála előtt vált az enyedi gyüjtemény részévé. Könyvtáráról rendelkező testamentumai közül az elsőben (Fogaras, 1753) azt a kívánságát fogalmazta meg, hogy halála után könyvei a nagyenyedi kollégium könyvtárába, második férje, gróf Teleki József (1675-1732) könyvei mellé kerüljenek. ${ }^{13}$ A későbbi, 1757-ben, Olthévízen keltezett végrendeletéből megtudjuk, hogy könyveinek nagyobb részét ekkor már átszállították a kollégium könyvtárába. Az otthonában maradt könyveiről pedig úgy rendelkezett, hogy halála után azokat szintén a kollégium könyvtárába juttassák, mivelhogy a már átadott könyveket kísérö jegyzékben fel vannak jegyezve. ${ }^{14}$ A nagyenyedi kollégium számára felajánlott gyüjtemény tehát egyetlen jegyzék kíséretében érkezett az enyedi könyvtárba 1757 körül, a másik része pedig utólag, valamikor 1759 után.

Bethlen Kata folyamatosan gyarapodó könyvgyüjteményének összetételéről elsősorban a Bod Péter (1712-1769) által - különbözö időszakokban - készített katalógusokból szerezhetünk tudomást. Időrendben az első jegyzék ,Árva B. Bethlen Kata Széki Teleki József úr özvegye könyveinek lajstroma" ${ }^{15}$ címmel 1747-ben készült, ennek autográf példányát a székelyudvarhelyi Tudományos Könyvtár őrzi, ez az ún. Udvarhelyi lajstrom. Egy másik katalógust Bod Péter 1752-ben

13 „...mindenkor az volt a szándékom, hogy kevés magyar könyveim lévén, azok az én holtam után adassanak az nagyenyedi kolegyiom számára, minthogy kedves édes férjem G. Teleki Jósef is a maga könyveit oda hagyván tétessék mellé." - SzÁDECZKY-KARDoss Lajos, Széki Gróf Teleki József özvegye Bethleni Bethlen Kata grófnö írásai és levelezése, 1700-1759, I-II. kötet, Bp., 1922-1923, 564-565.

${ }^{14}$ SzÁdecZKY-Kardoss 1922-1923, i. m. 573.

15 Nyomtatott kiadásai: LuKINICH Imre-KöBlös Zoltán, Gróf Bethlen Kata könyveinek katalógusa = Erdélyi Múzeum Új folyam, 1907, 2, 29-48; SzÁdeCZKY-KArdoss 1922-1923, i. m. 591-614; Erdélyi könyvesházak III, 1563-1757, A Bethlen-család és környezete, Az Apafi-család és környezete, A Teleki-család és környezete, Vegyes források, s. a. r. Monok István, Németh Noémi, Varga András, Szeged, 1994 (Adattár XVI-XVIII. századi szellemi mozgalmaink történetéhez, 16/3), 25-41. 
Halmágyi István kérésére állított össze „, Magyar bibliotéka, Avagy Mindenféle kiváltképpen pedig Teológiára tartozó Magyar Könyveknek Listájok: mellyeket maga számára gyüjtögetett a Méltóságos Gróf Asszony Bethleni Bethlen Kata asszony..." címmel, ${ }^{16}$ jelenlegi lelőhelye után (marosvásárhelyi TelekiBolyai Könyvtár) Marosvásárhelyi lajstromként tartják számon. A gyulafehérvári Batthyaneumban Bethlen Kata könyvjegyzékének újabb variánsa került elő, amelynek címe azonos a Székelyudvarhelyen őrzött jegyzékével: „Árva B.: Bethlen Kata Széki Teleki Josef Ur Özvegye Könyveinek Lajstroma", ${ }^{17}$ a másik két jegyzék példája alapján Gyulafehérvári lajstromként is említhetjük. A jegyzéket közlő Eva Mârza e harmadik, datálatlan jegyzéket is Bod Péternek tulajdonította. A mindösszesen 275 címet magába foglaló könyvjegyzék legfrissebb kiadású könyve 1748-ból származik, ebből arra következtethetünk, hogy a jegyzék is ekkortájt készült. Az Erdélyi könyvesházak harmadik kötetében Monok István, Németh Noémi, Varga András újraközölték a fent említett kiadásokat, javítva a nyilvánvaló hibákat. Bethlen Kata könyvtárának eddigi legteljesebb rekonstrukcióját Simon Melinda és Szabó Ágnes ${ }^{18}$ végezte el, kiegészítve az 1747-es és 1752-es jegyzékeket azokkal a címleírásokkal, amelyek bizonyíthatóan a gyüjtemény részét képezhették, 442 tételt sorolva fel.

Bethlen Kata könyvtárának 18. századi, eddig elökerült könyvjegyzékei

\begin{tabular}{|l|l|l|l|}
\hline & A könyvjegyzék címe & $\begin{array}{l}\text { A könyvjegyzék } \\
\text { készítője }\end{array}$ & Jelenlegi lelöhelye \\
\hline 1747 & $\begin{array}{l}\text { Árva B. Bethlen Kata Széki Teleki Jozsef ur } \\
\text { özvegye könyveinek Lajstroma }\end{array}$ & Bod Péter & $\begin{array}{l}\text { Tudományos Könyvtár } \\
\text { Székelyudvarhely }\end{array}$ \\
\hline 1748 & $\begin{array}{l}\text { Árva B.: Bethlen Kata Széki Teleki Josef Úr } \\
\text { Özvegye Könyveinek Lajstroma }\end{array}$ & Bod Péter & $\begin{array}{l}\text { Batthyány Könyvtár } \\
\text { Gyulafehérvár }\end{array}$ \\
\hline 1752 & $\begin{array}{l}\text { Magyar bibliotéka, Avagy Mindenféle } \\
\text { kiváltképpen pedig Teológiára tartozó } \\
\text { Magyar Könyveknek Listájok: mellyeket } \\
\text { maga számára gyüjtögetett a Méltóságos } \\
\text { GrófAsszony Bethleni Bethlen Kata asszony... }\end{array}$ & Bod Péter & $\begin{array}{l}\text { Teleki-Bolyai } \\
\text { Könyvtár } \\
\text { Marosvásárhely }\end{array}$ \\
\hline $\begin{array}{l}1762 \\
(1764 ?)\end{array}$ & $\begin{array}{l}\text { Cím nélküli } \\
\text { Benkő József }\end{array}$ & $\begin{array}{l}\text { Lucian Blaga } \\
\text { Egyetemi Könyvtár } \\
\text { Kolozsvár }\end{array}$ \\
\hline
\end{tabular}

${ }^{16}$ A könyvjegyzékeket közölte Boldizsár Kata Piroska, Gróf Bethlen Kata Magyar könyvtárának lajstroma = Erdélyi Múzeum Új folyam, 1912, 2, 162-190.

17 MÂrza Eva, Catalogul bibliotecii lui Bethlen Kata: varianta de la Alba Iulia = Emlékkönyv a Teleki Téka alapitásának 200. évfordulójára 1802-2002., szerk. Deé Nagy Anikó, SebestyénSpielmann Mihály, Vakarcs Szilárd, Mentor, Marosvásárhely, 2002, 401-422.

18 Simon Melinda, Szabó Ágnes, Bethlen Kata könyvtárának rekonstrukciója, Scriptum Kft., Szeged, 1997. 
A Benkő József által lemásolt, 1762-es datálású könyvjegyzék elvileg magába foglalja a Bethlen Kata által a nagyenyedi könyvtár számára adományozott teljes gyüjteményt, mintegy 390 mü címleírását tartalmazza. A kötetszám valamivel kevesebb lehetett, ugyanis, ha összevetjük a Benkő-féle listát Bod Péter lajstromaival, kiderül, hogy a korábban kolligátumként jegyzett egyes kötetek címeit Benkő külön közli. Példaként a Székelyudvarhelyi lajstromban szereplő tételt említjük: Jakab Angliai Királly, Királlyi ajándéka, meljben tanitja a'fiát kegyes országlásra. magyarra forditotta Szepsi Korotz György. Nyom. Oppenheimben 1612. 12 Részben. Ehez vagyon ragasztva az Botskai István Fejedelem Homonnai Druget Balint Mágotsi Ferentz urak Epitafiumjaik. Benkő az epitáfiumokat külön címként jegyzi. Ugyanakkor a Gyulai Ferenc halálára írt halotti oratiokat tartalmazó kolligátumot egyetlen összefoglaló cím alatt adja.

A Bethlen Könyvtár 1764-ben indított katalógusából kitünik, hogy a magyar nyelvü könyvek kezdetben az adományozóik tékáiban kerültek bejegyzésre, s csak a későbbiekben hozták meg azt a döntést, hogy az összes hungarikaanyagot egybegyüjtve, egységes, különálló gyüjteményt hozzanak létre. Jól illusztrálja a fenti gondolatmenetet Teleki József adománya: az 1764-es katalógusban bejegyzett Theca Telekiana magyar nyelvü könyveinek egy része mellé a regisztrációt követő években bejegyezték, hogy az illető mü átkerült a Hungarika tékába (Translatus in Theca Hungarica). Az elkövetkező időszakban újabb beszerzéseknek köszönhetöen a hungarika-gyüjtemény folyamatosan bővült, így Benkő Ferenc 1796-ban e gyüjtemény nagyságát 520 kötetben határozta meg. ${ }^{19}$

\section{A Benkö-féle enyedi hungarika-könyvjegyzékröl}

A továbbiakban a Benkő által 1762-ben, a nagyenyedi kollégiumban lemásolt könyvjegyzékkel kívánunk foglalkozni. Benkő József későbbi munkássága rendkívül sokrétü: egyháztörténeti és történelmi, alkotmány- és jogtörténeti munkák mellett genealógiai, néprajzi és természettudományi, valamint nyelvmüvelési és irodalomtörténeti kérdésekkel is foglalkozott. Irodalomtörténeti munkássága keretében többek között, kortársaihoz hasonlóan, kiegészítette Bod Péter ${ }^{20}$ Magyar

19 „Az ajtón belöl jobbkézre vagyon a’ Magyarthéka, mely a’ n. b.e.R.Sz.B. Gróf Nagy Teleki Jósefné született Gróf Bethlen Kata Aszszony drága ajándéka, egyenlő szép kötésekben, és a' kegyes Jótevőnek nevével meg-bélyegezve, melyeknek a' számok ujjabbakkal-is szüntelen szaporíttatván ma már mintegy 520 darabokból áll...”. - BENKő Ferenc, Enyedi ritkaságok,1800, Kiss Erika és Viskolcz Noémi tanulmányával, Fakszimile kiadás, Szeged, Szegedi Egyetem, Juhász Gyula Pedagógusképző Kar, 2010 (A Tudástár Füzetei, 1), 40-41.

${ }^{20}$ Benkő József és Bod Péter kiváló szakmai kapcsolatban álltak egymással, amit igazol az 1767-ben megjelent Dictionarium Latino-Hungaricum et Hungarico-Latino-Germanicum címü szótár, amelynek munkálataiban (önálló gyűjtéssel) Benkő is részt vett. - ÉDER Zoltán, Benkő József nyelvészeti munkássága és az Erdélyi Magyar Nyelvmüvelö Társaság, Bp., Akadémiai, 1978, 41-45. 
Athenását. Ennek kapcsán Benkő levelezést ${ }^{21}$ folytatott Sófalvi József (17451794) református lelkésszel, kolozsvári kollégiumi tanárral, majd később 1786ban Szathmári Pap Mihály (1737-1812) és Szerencsi Nagy István (1728-1789) győri református lelkész ${ }^{22}$ fordul Benkőhöz ez ügyben. Tölük függetlenül, a lexikon folytatásán munkálkodott Keresztesi József ${ }^{23}$ nagyváradi református lelkész (1786) is, nyomtatásban azonban egyik munka sem jelent meg. Elképzelhetőnek tartjuk, hogy Benkő József Additamenta ad Notitiam Scriptorum Historiae Hungaricae Clar[issimi] Quondam Petri Bod in Ecclesia Ref. M. Igenensi V. D. M.: Bod Magyar Athénássára való Pótlások ${ }^{24}$ címü kéziratban maradt munkájának megírásához forrásként felhasználta az enyedi könyvtár magyar könyveinek jegyzékeit is. Az Addidamenta ... lapszámozása - 406-tal kezdődik és 449-ig halad - azt mutatja meg, hogy egy nagyobb terjedelmü kézirat-kolligátumnak volt a része. 25

Benkő József kéziratában 88 szerző mủvének újabb kiadásaira fókuszál, életrajzi kiegészítéseket csak elenyésző számban végez, helyenként tartalmi vonatkozású megjegyzéseket, kiigazításokat tesz. Adatainak megbízhatóságát az újabb kiadások terjedelmének jelzése biztosítja. Feltételezzük, hogy csak azokról a nyomtatványokról közöl újabb információkat, amelyeket kezében forgatott. Példaként Áts Mihály nagy népszerüségnek örvendő Aranyláncát említjük, amely az enyedi könyvjegyzékben a szerző nevének feltüntetése nélkül szerepel. Bod Péter $M a$ gyar Athenásában az 1706-os kiadást ismerteti, Benkő József mindezt megtoldja

${ }^{21}$ Benkő József levelezése, a leveleket összegyüjt. és a jegyz. szerk. Szabó György, Tarnai Andor, Bp., MTA Irodalomtudományi Intézete, 1988, 216, 274, 283 számú levelek; TARNAI Andor, Bod Péter $=$ Uö, Tanulmányok a magyarországi historia litteraria történetéröl, Bp., Universitas, 2004, 135.

${ }^{22}$ Bellágh Rózsa, Szerencsi Nagy István a Magyar Athenás folytatója = Az Országos Széchényi Könyvtár Évkönyve, 1990, 417-433.

${ }^{23}$ Uö, Keresztesi József és a Magyar Athenas toldaléka = Magyar Könyvszemle, 1995, 1, 90-94.

${ }^{24}$ [BenKö József], Additamenta ad Notitiam Scriptorum Historiae Hungaricae Clar. Quondam Petri Bod in Ecclesia Ref. M. Igenensi V. D. M.: Bod Magyar Athénássára való Pótlások. Jelzete a Kolozsvári Akadémiai Könyvtárban (továbbiakban KvAkKt): Ms.U.1725, 406-449. (Pecséten: Unitárius Gimnázium Könyvtára Székelykeresztúr.)

${ }^{25}$ Mikó Imre Bod Péter Necessaria ac utilis scriptorum Historiae Notitia... címü munkájának ismertetése kapcsán arra utalt - amelyet a kézirat lelőhelyének megjelölése nélkül, 405 oldalas müként prezentál -, hogy a Bod-féle kézirat Benkő József javításait tartalmazza. Bod Péter müve tehát Benkő tulajdonában volt, s annak folytatásaként (406-449) feltehetően Bod Magyar Athenására való Pótlását hozzáfüzte. (Mikó 1867, i. m. 168-169). Később Musnai László, az enyedi könyvtár kéziratait bemutató tanulmányában, Bod Péter Necessaria ... címü művének enyedi jelenlétére hívta fel a figyelmet. Állítása szerint a kéziratot 1768. július 5-én Sárdon keltezték, s Benkő József jegyzeteivel van kiegészítve. A lapszámozás 294-gyel kezdődik és 402-ig halad, majd további két oldalon jegyzeteket tartalmaz. A kolligátum valószínű 1798-ban került az enyedi könyvtár tulajdonába, amikor 700 forintért Benkő számos kéziratát megvásárolták. Elképzelhető, hogy Mikó Imre és Musnai László ugyanarról a kézirat-kolligátumról beszéltek, de időközben a kolligátumot szétválasztottak, s a 20. századig ennek töredéke maradt a könyvtár tulajdonában. (MusNAI László, A Bethlen Kollégium Nagykönyvtárának értékes kéziratai = Református Szemle, 1940, 170.) 
az 1760-as kiadással, amelyhez tartalmi annotációt füz. ${ }^{26}$ Hasonlóképpen Beniczky Péter Magyar rithmusok címü kötetéről Bod csupán annyit jelez, hogy sokszor nyomtatták ki, Benkő három kiadásról tud. ${ }^{27}$

Korábban utaltunk már arra, hogy a Benkő József által lemásolt, szerzői betürendbe sorolt, többnyire impresszummal ellátott könyvjegyzék datálásából arra következtethetünk, hogy a nagyenyedi Bethlen Könyvtár Hungarika Tékájának 1762. esztendei gyüjteményét foglalja magában, amelyet feltehetően maga a másoló egészített ki. Bethlen Kata halálát követően kiadott müvek betürendbe sorolva, és nem a jegyzék pótlásaként jelennek meg, ami azt valószínüsíti, hogy nem a Bethlen Kata enyedi könyvadományával érkező listával állunk szemben.

A kalligrafikusan írt jegyzék egyes tételei csillagocskákkal vannak ellátva. Ezt a jelölési módot 1752-es lajstromában Bod Péter saját könyveinek jelölésére alkalmazta. Nem sikerült tisztázni, vajon milyen céllal emelte ki Benkő József e címeket. Lajstromában Szentpéteri István Debrecenben kiadott Ördög szigonya (RMK I. 1538), illetve Hangos tombitája (RMK I. 1521) mellé bejegyezte, hogy egybe vannak kötve, azt azonban nem állíthatjuk, hogy az összes megjelölt tétel kolligátum lenne.

Bethlen Kata korábbi könyvjegyzékeihez képest, a Benkő-féle jegyzék meglehetősen nagyszámú, felesleges utalóval van teletüzdelve: Pázmány Péternek A nagy Calvinus Jánosnak hiszek-egy-istene címü, 1726-ban Csíksomlyón kiadott munkáját Calvinnál, illetve Kalvinnál is felvette a jegyzékbe, Pázmány nevét mellőzte a regisztráló, és a sort további példákkal folytathatnánk.

A könyvkatalógus újdonságát egyrészt az adja, hogy a korábbi három, Bod Péter által összeállított könyvjegyzékhez képest mennyiségileg valamivel nagyobb gyüjteményt regisztrál. Másrészt Benkő az általa jól ismert kiadványok mellé tartalmi vonatkozású megjegyzéseket füzött. Olyan munka is fellelhető benne, amelyröl mindeddig a szakirodalom csak feltételezte, hogy megvolt az enyedi könyvtárban, bizonyíték mindeddig nem került elö. Mielőtt a fentiekben felsoroltakat példákkal támaszthatnánk alá, pontosítsuk a könyvjegyzék datálását.

A jegyzéket készítője 1762. szeptember 16-i keltezéssel látta el. Figyelmesen végigolvasva a lajstromot azonban kiderült, hogy annak legfrissebb kiadványa a Bonóniai Mese címet viselő tétel. Ez nem lehet más, mint Benkő József első, latin nyelvből fordított verses diákkori munkája, amely nyomtatásban 1764-ben Nagyenyeden jelent meg. Következésképpen a könyvjegyzéket 1762-től kiegészítették, utolsó bejegyzése 1764-ben készült.

26 „Áts Mihály, Arany láncz, ... Lőcsén, 1706. in $12^{\circ}$ Augostában 1760. Pag. 240+4. Nagyobb részént abból vagynak vétetve a Bujdosás emlékezet kövében lévő imádságok és az imádságok végein való versek is.” BENKÖ i. m. Ms.U.1725.

27 „... mint a Bartók István Esztergami vicarius Praefatiojából látszik 1664-ben kinyomtattatott Lőtsén is 1728ban pag 288x22. Debretzenben 1756. Kállai Gergelynél pag. 298.x22.” BENKö, uo. 


\section{A könyvjegyzékhez mellékelt annotációkról}

A továbbiakban a Benkő József által bejegyzett néhány annotáció értelmezésére teszünk kísérletet, amelyekkel az egyes címleírásokat kiegészítette. Az itt felsorolásra kerülő tételek hiányos, impresszum nélküli regisztrációja miatt lehetetlen részletes bibliográfiai leírást adni, noha a kiadás jelzése értékes információként szolgálna.

Vegyük elsőként az impresszum nélkül bejegyzett Salamon királynak, az Dávid király fiának Markalffal való tréfabeszédeknek rövid könyve címü trufáskönyvet, amelyet a felvilágosodás korában a müveletlen emberek olvasmányaként tartottak számon. ${ }^{28}$ Tartalmát tekintve a könyv Salamon királynak bizonyos Markalf nevü furfangos paraszttal való beszélgetését foglalja magában. A címleírásból sajnos nem derült ki, hogy a mü mely kiadásával rendelkezett a könyvtár, azonban tudjuk, hogy a rendkívül nagy népszerüségnek örvendő munka magyar nyelven először 1577-ben Kolozsváron, Heltai Gáspár műhelyében ${ }^{29}$ jelent meg, s a 18. századig több kiadást is megért. ${ }^{30}$ Címleírása mellé Benkő a következő bejegyezést tette: „Ez igen átkozott vétkes Könyv. Vajha az efféléknek nyomtatása helyet jó dolgokra fordítanák a' Magyarok a Typographiát." Benkő bírálatát valószínüleg a könyvnek a Bibliától eltávolodó nyers, paródiaszerü előadásmódja váltotta ki. ${ }^{31}$ A népszerü, szórakoztató ponyvanyomtatványoknak az erdélyi református eklézsia képviselői részéről érkező bírálata nem újkeletű, elsősorban a nyomtatványoknak az egyház tanításaitól eltérő tartalmuk miatt. Korábban Misztótfalusi Kis Miklóst is a ponyvakiadványok nyomtatásával vádolták meg, amiért Mentségében (1698) védekezni kényszerült: „,Azzal óltsárlák igyekezetemet, hogy én-is tsak ollyan apróságot, Argirust, Tékozlót, Aszszonyokról való 's egyébb hijjába való históriákat nyomtatok, és nem a' mint reménlették, derék könyveket...". ${ }^{32}$ Tudjuk, Misztótfalusi anyagi szempontból kényszerült a ponyvanyomtatványok kiadására, úgyanis ezekre volt nagyobb igény, s a nyomtatás költségei is hamarabb megtérültek. ${ }^{33}$

${ }^{28}$ HoRvÁth János, A reformáció jegyében: a mohács utáni félszázad magyar irodalomtörténete, Bp., Gondolat, 1957, 394.

${ }^{29}$ RMNy 389.

${ }^{30}$ Vö. Holl Béla, A Salamon és Markalf magyar kiadásairól = Magyar Könyvszemle, 1965, 4, 349-352.

${ }^{31}$ Példaértékü a könyv alábbi részlete: Salamon: A szünek böüségéből szól a száj. Markalf válasza erre: Hasnak teli voltából trombitál a segg. A Bibliában Jézus mondja, hogy „,Szívnek teli voltából szól a száj” (Máté 12,34). Magyar elbeszélők 16-18. század, a válogatás Gyenis Vilmos és S. Sárdi Margit, a szöveggondozás és jegyzetek S. Sárdi Margit munkája, Bp., Szépirodalmi Könyvkiadó, Bratislava, Madách Könyvkiadó, 1986 (Magyar remekírók), 51.

${ }^{32}$ M. Tótfalusi K. Miklósnak maga személyének, életének, és különös tseledeketeinek mentsége, mellyet az irigyek ellen, kik a' közönséges jónak ezaránt meggátlói, irni kénszerittetett: Kolozsváratt, 1698. Esztendöben, mellyet most ujjolag kinyomtattak Tolnai Gábor bérekesztő-beszédével, Facsimile kiad., Gyoma, 1940, 46.

33 „Amiből látja a szegény legény, hogy hasznocska jö, azt nyomtathatja. Derék könyveket itt 
A babonaság, a csillagokból való jóslás, amit a korabeli szerencsekönyvek népszerüsítettek, ${ }^{34}$ az akkoriban még teológushallgató Benkő isteni gondviselésbe vetett hitével összeegyeztethetetlen volt, így a Szerentse Kerék címen lejegyzett könyvet Léha Könyvként stigmatizálta. Feltehetően a rendkívüli népszerüségnek örvendő, magyar nyelvű sorsvető könyvről van szó, amely a Fortuna, azaz szerentsének, avagy szerentsétlenségnek kereke címen jelent meg, ${ }^{35}$ amelynek legkorábbi kiadása Kolozsváron (1604) ${ }^{36}$ és Bártfán $(1603)^{37}$ látott napvilágot. Ezt követően a 19. századig tizenhat kiadást ért meg. A magyar világi ponyvairodalom azonos kategóriába sorolja az Álomfejtö Könyvetske címen bejegyzett munkát is, amelynek első kiadása a Fodorik Menyhért Álomkönyveczke (1635) címen látott napvilágot, s a továbbiakban több kiadást is megért (pl. 1722 Nürnberg, 1756 Buda).

Pázmány Péter legvakmerőbbnek tartott vitairata, A nagy Calvinus Jánosnak hiszek-egy-istene... 1726-ban Csíksomlyón ${ }^{38}$ kiadott példánya mellé Benkő a következő bejegyzést tette: ez igen átkozott Könyvetskéje ellenünk a' Pápistáktol.... Ha fellapozzuk Benkő József Magyar Athenashoz való pótlásának kéziratát, Pázmány müvének hasonló hangvételü leírásával találkozunk: „Calvin János Istene. Az az Demonstratio, mely által meg-mutattatik, hogy mind ö maga, mind követöi igaz Bálvány imádok. Nyomtattatott a'Csiki Klastromban 1726. I. C. in 8vo. Pag 95. Iszonyu káromkodásokkal ’s hazugságokkal tellyes örök tüzre méltó Könyv, mellyben az az Istent áhit Calvinus és minden Calvinista imád hazug Istennek Tyrannus bolond, esztelen, irgalmatlan nem mindenható magában bünös tudatlan Istennek káromoltatik. Pag. 1. 2. Vagyon ajánlva L. B. Kászoni Bornemisza János Josefnek Gubernalis Consilliariusnak és Erdéllyi Fö Cancellariusnak. "39 A fenti kötetekhez hasonlóan Bethlen Kata könyvtárának eddigi könyvjegyzékei nem tartották nyilván ezt a müvet, ennek eddig számon tartott egyik példánya Bod Péter tulajdonában volt. ${ }^{40}$

Szentmártoni Bodó János (1590?-1648) 1622-től torockószentgyörgyi, majd 1634-től kolozsi unitárius lelkész a szerzője annak a históriás éneknek, amelyet a 18. századi protestáns ponyvanyomtatványok egyik legnépszerübb kiadványa-

hiába nyomtatnánk, ha lehetne is; efféle aprólék débdábon, ami olcsó, mégis inkább kapnak; amint szinte akkor jöve híre, hogy azt igen kapták Enyeden, és ami ott volt, mind elfogyott." Uo. 82.

34 Pogány Péter, A magyar ponyva tüköre, Bp., Európa, 1978, 221-236.

35 Lásd erre vonatkozóan: BoRsa Gedeon, Hol és mikor nyomták az eddig ismert két legrégibb magyar sorsvetö könyvet? = Magyar Könyvszemle, 1964, 4, 348-354; Uö, A „Fortuna” sorsvetö könyvek eredete és utólete = Magyar Könyvszemle, 1966, 1, 75-81.

${ }^{36}$ RMNy 916.

37 RMNy 892.

38 Petrik I. 375.

39 Benkő József, Additamenta ad Notitiam Scriptorum Historiae Hungaricae Clar. Quondam Petri Bod in Ecclesia Ref. M. Igenensi V. D. M.: Bod Magyar Athénássára való Pótlások, KvAkKt Ms.U.1725, 428.

${ }^{40}$ Radvánszky Béla, Bod Péter könyvtárának jegyzéke = Magyar Könyvszemle, 1884, 58-56. 
ként tartanak számon, ${ }^{41} \mathrm{~s}$ amelyet Benkő „Mária Magdalénáról való versek, mellyeket irt egy haszontalan unitárius ember" ${ }^{42}$ címként jegyezett le. Valószínü, hogy a „haszontalan unitárius ember” megrovás Szentmártoni Bodó Jánost az 1636. esztendőben bekövetkezett büntetése miatt minősíti, amikoris a kolozsvári egyetemes elmarasztalta. ${ }^{43}$

A következő bejegyezés a Fige fészek címü nyomtatvány mellett áll: „,Ez igen ritka Könyv, és a' mint hallottam 3. Kérd[ésre] felel meg. "44 Benkö jegyzete téves, ugyanis a könyv nem három, hanem öt kérdésről értekezik, éspedig: a bünről és a megtérésről, az isteni gondviselésről, a részegségről és a józanságról, a békességről és a béketelenségről, a fösvénységről és az adakozásról, abban viszont igazat adhatunk neki, hogy valóban ritka könyvről van szó: Szabó Károly egyetlen példányt jelez, amelyet jelenleg a kolozsvári Egyetemi Könyvtárban unikumként tartanak nyilván. ${ }^{45}$

Az irodalomtörténeti szempontból igen jelentős, rendkívül népszerü, ám a 17. században megvetett ponyvakiadványként számon tartott Argirus Historiáját Misztótfalusi ócsárlói is „,hijjába való história”-ként emlegették. Benkő József könyvjegyzékében Gergei Albert művét „,Argirus Historiája, melyben szinnel le-festett Erdélly Országa Olasz nyelven, ’s azután forditatott Magyar versekre. Lásd erröl Husztit” formában, sajnos, impresszum nélkül rögzített, így nem tudni, a mü mely kiadásáról készült a leírás. Tudjuk, hogy a mü első máig fennmaradt, nyomtatott töredéke 1630-ból származik. ${ }^{46}$ Benkő József az 1778-ban megjelent Transsylvaniaban az Argirus-széphistóriának allegorikus értelmezését láttatja: Argirus Traianus császár, aki a tündérlányt, Daciát (Erdélyt) akarja meghódítani. A 19. század irodalomtörténészei, köztük Heinrich Gusztáv, Benkő elképzelését önhitt tudákosságnak, tudós tákolmánynak minősítette. ${ }^{47}$ Később azonban Gulyás József Benkö József becsülete ${ }^{48}$ címü tanulmányában arra a következtetésre jutott, hogy a széphistória értelmezéséhez Benkő forrásként Huszti András ,„Ó és ujj Dácia az az Erdélynek régi és mostani állapotjárról való história" címü müvét használhatta, noha munkájában erre nem hivatkozott. A tanulmány azt is feltételezte, hogy

${ }^{41}$ Vö. TÜSKÉs Gábor, Vallásos ponyvanyomtatványok a XVIII. században = TÜSKÉs Gábor, Knapp Éva, Az egyházi irodalom müfajai a XVII-XVIII. században, Tanulmányok, Budapest, Argumentum, 2002 (Irodalomtöténeti füzetek, 151), 249.

${ }^{42}$ Szentmártoni Bodó János, História az Mária Magdolnának sok büneiböl való, jó reménység alatt, kegyes megtéréséről... című münek első kiadása Lőcsén 1683-ban jelent meg (RMK I. 1311.), a következő Kolozsváron 1703-ban (RMK II. 1671), 1762-ig több kiadása is ismert.

${ }^{43}$ MaMüL, föszerk. Köszeghy Péter, XI, Bp., Balassi, 2011, 122-123.

${ }^{44}$ Marosi István, Füge fiszek, mellyben Öt tojások vannak az az: Öt-féle dolgokban tébolygó elmének utban igazitása. Apoc. 3. Vers 15. Tudom a te dolgaidat, hogy te sem hideg nem vagy, sem hév, Kolozsvár, nyomtatta Veresegyházi Mihály 1672-ben (RMK I. 1129.)

${ }^{45}$ A könyv digitális változata: http://dspace.bcucluj.ro/handle/123456789/21962, Kölcsey[!] Zsigmond posszeszorbejegyzéssel.

${ }^{46}$ MaMüL, 2005, III, 264.

${ }^{47}$ HeIrich Gusztáv, Árgirus = Budapesti Szemle, 1889, 167.

${ }^{48}$ GulYÁs József Benkő József becsülete = Irodalomtörténeti Közlemények, 1913, 451-454. 
Benkő hozzáférhetett Huszti munkájához, ugyanis az 1736-ban megírt és 1791ben Bécsben kiadott müvet Tömösvári Sámuel 1763-ban épp Enyeden másolta le. A fentiekhez az enyedi könyvjegyzékben szereplő címleírás alapján azt tehetjük hozzá, hogy Benkő Józsefnek valóban Huszti volt a forrása, hiszen a címleírásban utal erre (Lásd erröl Husztit), másrészt a könyvjegyzékben felbukkan Huszti Erdélyröl való Historiája. Tit.: Ó és Uj Dacia címü, nagy valószínüséggel kéziratos munkája, amely a rendelkezésére állhatott.

A nagyenyedi lajstromban a Balassa Bálint (1554-1594), illetve Benitzky Péter (1606-1664) Bethlen Kata gyüjteményéből származó kötete mellett megjelenik Gyöngyösi István (1629-1704) Chariclia Magyar Versekke ${ }^{49}$ címü munkája, illetve a szintén Gyöngyösinek tulajdonított Cuma Várossában épült Dedalus Temploma ${ }^{50}$ című fordítás. Gyöngyösi e két munkájának nagyenyedi jelenlétét csupán ebben a jegyzékben regisztrálták.

A 18. században nagy népszerüségnek örvendő Kádár énekeként ${ }^{51}$ jegyzett mü Bod Péter egyik lajstromában sem szerepel, provenienciáját nehéz lenne meghatározni, valószínünek tartjuk, hogy ennek legkorábbi kiadásáról van szó. Az ismeretlen szerzőjü Nyúl éneke, illetve Felvinczi György könyve, a Bellorum morborum az az nyavalyák históriája ... címü munkák, allegorikus mondanivalójuk miatt, több kiadást is megértek és szintén nincsenek regisztrálva Bethlen Kata korábbi könyvjegyzékeiben.

Pápai Páriz Ferenc (1649-1716) bibliai témájú drámája, az Ábrahám Pátriárcha fia Isak és Bathuel leánya Rebeka házasságok alkalmatosságával lött beszélgetés..., ${ }^{52}$ amelyet Bethlen Miklós lánya, Bethlen Júlia és Teleki Sándor 1703 március 3-án megtartott esküvője alkalmából írt, szintén része volt a Hungarika tékának. Pápai Páriz Ferenc unikumként nyilvántartott munkája az enyedi minorita régikönyves gyüjteményből 2005-ben került a kolozsvári Egyetemi Könyvtár gyüjteménybe.

\section{A könyvjegyzék kéziratairól}

Benkő Ferenctől (1745-1816) tudjuk, hogy az nagyenyedi Bethlen Könyvtárban a kéziratokat csupán 1796-ban választották külön a könyvektől, ${ }^{53}$ ezért a 18. század közepén indított katalógusokban a kéziratokat még a könyvek között tartot-

49 Első kiadása 1700-ban Lőcsén jelent meg, ezt követően a 18. század elején több kiadása is ismert.

${ }^{50}$ Nyomdahely nélkül 1724-ben jelent meg.

${ }^{51}$ [KöDI-FARKAS János], Vitéz Kádár Istvánnak históriája melly az õ fegyver-viselésének végsõ részét foglalja bé, és mostan e' kis formában... ujionnan ki-nyomatatot[!]. Budán, ebben az esztendöben. [1760 körül, Landerer.] - Petrik V. 272.

52 A lajstromban Isák Rebekával való Házassága Versekben címen jelenik meg.

53 „Két üveges Théka készittetett itten a’ Manuscriptumoknak vagy Kézirásoknak, a’ mellyek most kezdettenek számba vétetni, és igyekezet vagyon azokat meg-szaporítani, mellyek eddig ke- 
ták számon. A lajstromunkban szereplő kéziratokat illetően három olyan címről számolhatunk be, amelyek a Bethlen Kata könyveit egybegyüjtő listák egyikén sem kerültek bejegyzésre. Tserei János [Mihály] Historiája, a'Kurucz világ dolgairól kéz irásban foliant-ként jegyzett kézirat szerzőjének nevét elírták, Benkő kéziratos kolligátumának második könyvkatalógusában helyesen, Cserei Mihály munkájaként jegyezték be. Cserei Mihály (1667-1756) Erdély históriájának a 18. században számos kéziratos másolata forgott közkézen Erdélyben. Benkő József kissé túlzottnak tünő megállapítása szerint Cserei munkájának legalább háromszáz másolata létezett ,, $S$ mindenfelé találtatott", ${ }^{54}$ így ennek enyedi jelenléte egyáltalán nem meglepő. A Huszti András korábban már említett, Ó és Ujj Dacia... címü munkáját szintén a kéziratok közé soroljuk - noha annak kéziratos voltára nem utal a jegyzék - ugyanis ennek nyomtatott változata csupán 1791-ben jelent meg. Szent Makárius legendájának ${ }^{55}$ egyik kéziratos változatát a Teleki-kódexböl ismerjünk. ${ }^{56}$ A Teleki-kódexet (1525-1531) Aranka György 1810-ben adományozta a Teleki Tékának, a kézirat korábbi sorsáról semmit sem tudni. Külön figyelmet érdemel Krisztus szenvedésének Histor. Le kótázva nyomtatásban fol. formában regisztrált munka, amelyet az enyedi Hungarika Téka kéziratként jegyez: Jésus Cxtus Szenvedéseinek Historiája. M.S. Bod Péter 1747-es katalógusában Sz. Páli István kántornak tulajdonította a munkát, a következő címmel: Kristus Urunk szenvedésének históriája, amint szokott énekeltetni: irta le Sz. Pali István Kántor $4 R$. Az egymásnak ellentmondó (kézirat vs. nyomtatott mü) címleírások alapján mindezidáig Szentpáli István múve azonosítatlan maradt.

Külön kiemeljük Kocsi Csergő Bálint munkáját, amely Bod Péter fordításában Kösziklára épült ház ostroma címen vált ismertté, s amelynek a 18. században számos kéziratos változata forgott közkézen, ${ }^{57}$ elsősorban azért, mert annak kiadására a kedvezőtlen politikai konjunktúra miatt gondolni sem lehetett. A munka népszerüségét igazolja, hogy a 18 . század végén az enyedi könyvtár négy példánnyal is rendelkezett: időrendben az elsőt 1770-ben Csató Ferenc másolta le Enyeden, 1773-ban Kolozsváron M. S., 1776-ban Debrecenben I. L., valamint 1815-ban Csiszér Sámuel magyarigeni rektor. Egykori alumnusaként Bod Péter ezt a munkát Bethlen Katának ajánlotta, így nem meglepő, hogy ennek

vés számmal voltak, más Thékákban lévén széllyel, holott a kézirások nagyon nevelik a’ Könyvesházaknak érdemeket..." BeNKö Ferenc 2010, i. m. 56-57.

${ }^{54}$ Benkö József tudósitása az Erdély Históriája Iróinak magyar nyelven található kézírásaikról, közli Bruz Lajos, Kiad. Toldy Ferenc = Új Magyar Muzeum, 3(1853), 5. füzet, 233. - A Benkő József által megítélt háromszáz kéziratos példányból 1963-ban már csak 48-at regisztráltak. Vö. Repertoriul manuscriselor de cronici interne sec. XV-XVIII., szerk. Crăciun I., Ilieş A., Bucureşti, Ed. Academiei Republicii Populare Române, 1963, 353-359.

55 Benkő könyvjegyzékében a következő formában szerepel: „Makarius fordítatott Kéz Irásban”.

${ }^{56}$ Sz. Makárius élete = Nyelvemléktár, Teleki Codex, 12. Közzéteszi Volf György, Bp., 1884, 373-387.

${ }^{57}$ Bretz Annamária, Bod Péter forditása Kocsi Csergő Bálint Narratio breviséből című tanulmányában összegzi az általa fellelt másolatokat = Irodalomtörténeti Közlemények, 2004, 3, 340-347. 
egyik változata a Hungarika téka részét képezte. Napjainkban a Bethlen Kata könyvtárából származó másolat a kolozsvári Egyetemi Könyvtár kéziratgyüjteményének része. ${ }^{58}$

Összegzésként elmondhatjuk, hogy a Benkő József által lemásolt könyvjegyzék-, Bethlen Kata által a nagyenyedi Bethlen Könyvtárnak adományozott hungarikagyüjtemény legteljesebb, vélhetően az 1764. esztendőig kiegészített kollekcióját adja. A jegyzékben újdonságnak számít a vallásos, illetve a világi ponyvanyomtatványok jelenléte, amelyeket Bod Péter korábbi három könyvjegyzékében nem regisztrált. Nem egyedülálló jelenségről lenne szó, Monok István egyik tanulmányában ${ }^{59}$ arra hívta fel a figyelmet, hogy a koraújkori arisztokrata könyvtárak katalógusaiban csak ritkán jegyezték fel az értéktelennek számított nyomtatványokat, inkább mellőzték regisztrálásukat. Bod Péter számára a ponyvakiadványok bizonyára nem bírtak jelentősebb értékkel, így feltehetően ennek okán nem jegyezte fel őket.

\section{RÁCZ, EMESE}

\section{Le catalogue de hungarica de Benkő József á Nagyenyed}

Notre étude est consacrée à la présentation de deux catalogues hungarica, encore inexplorés, reliés dans un colligat ayant appartenu à József Benkő, pasteur réformé et érudit transylvain. Le colligat est conservé aujourd'hui á la Bibliothèque Universitaire de Kolozsvár. Le premier de ces catalogues, organisé en ordre alphabétique, muni d'un bon à tirer, a été copié par Benkő, étudiant en théologie á l'époque, en 1762. Il s'agit probablement des hungarica de la Bibliothèque Bethlen. La collection hungarica de la bibliothèque d'Enyed remonte à la donation faite par Kata Bethlen - une partie des livres est arrivée à Nagyenyed en 1757, le reste en 1759, après la mort de la comtesse. Le catalogue établi par Benkő enregistre la collection entière, composée de 390 livres. Benkő annota également un certain nombre de titres - dans notre étude, nous traiterons en détail ces annotations aussi.

Le second catalogue en question est celui de la collection hungarica de la Bibliothèque Bethlen $\mathrm{du} 18 \mathrm{e}$ siècle. Sa construction est identique au catalogue manuscrit de 1764, qui organise la collection en différentes bibliothèques et en différents ordres. L'importance de ce second catalogue réside dans le fait que les spécialistes ont jusqu'à ce jour ignoré la composition exacte de la collection hungarica de la bibliotheque d'Enyed. Dans notre étude, nous nous efforçons de tirer au clair quand et comment Benkő s'est procuré le catalogue en question et aussi l'usage qu'il en a fait dans son activité scientifique.

Keywords: library catalogue, 18. century, Transylvania, Nagyenyed (Aiud, Strassburg am Mieresch), aristocratic libraries, Bethen Kata, historiography

${ }^{58}$ KvEKt, jelzete: MSS 1348. - A könyvet Szilágyi Sándor történész 1895-ben, doktorrá avatása alkalmából adományozta a kolozsvári Egyetemi Könyvtárnak. A címoldal rectóján Bethlen Kata nyomtatott ex librisének jól kivehető maradványa olvasható: A. B. Bethlen Kata G. Teleki Josef özvegye könyvei közzül való. Szilágyi Sándor 1866-ban Lipcsében kiadta Kocsi Csergő Bálint munkáját, amelynek valószínű ez a példány volt egyik forrása.

59 MonoK István, A magyarországi és erdélyi arisztokrácia és a „,mindenkinek szóló könyv” a 17-18. században = Magyar Könyvszemle, 2013, 4, 449. 